\title{
PENGARUH ROLE PLAY DALAM KONSELING KELOMPOK UNTUK MENURUNKAN TINGKAT BULLYING SISWA (Studi Kuasi Eksperimen Terhadap Siswa Kelas XII di SMK Negeri 41 Jakarta)
}

\author{
Putri Nuliandini ${ }^{1}$ \\ Wirda Hanim ${ }^{2}$ \\ Atiek Sismiati S. $^{3}$
}

\begin{abstract}
Abstrak
Penelitian ini bertujuan untuk mengetahui pengaruh role play dalam konseling kelompok untuk menurunkan tingkat bullying peserta didik kelas XII SMK Negeri 41 Jakarta. Metode yang digunakan adalah kuasi ekperimen dengan pretest-posttest nonequivalent control group design. Sampel dalam penelitian ini berjumlah delapan belas orang siswa kelas XII SMK Negeri 41 Jakarta yang diambil dengan menggunakan purposive sampling. Pengumpulan data dilakukan dengan menggunakan instrumen tingkat bullying. Hasil uji hipotesis dilakukan dengan bantuan program SPSS 20.0 yang menunjukkan bahwa tingkat bullying memperoleh $\mathrm{Sig}=0,002$, yang berarti lebih kecil dari nilai signifikansi $\alpha$ 0.05. Dapat disimpulkan bahwa $\mathrm{H}_{0}$ ditolak dan $\mathrm{H}_{1}$ diterima. Hasil penelitian menunjukkan penurunan tingkat bullying peserta didik yang mendapatkan layanan konseling kelompok dengan metode role play lebih tinggi dibandingkan peserta didik yang tidak mendapatkan layanan konseling kelompok dengan metode role play. Berdasarkan penelitian yang telah dilakukan, role play dalam konseling kelompok berpengaruh terhadap penurunan tingkat bullying siswa. Oleh karena itu, guru bimbingan dan konseling dapat menjadikan role play dalam konseling kelompok sebagai salah satu bentuk alternatif penanganan untuk menangani siswa yang memiliki tingkat bullying yang tinggi.
\end{abstract}

Kata kunci: bullying, metode role play, konseling kelompok

\section{PENDAHULUAN}

Kekerasan dalam dunia pendidikan merupakan salah satu fakta yang masih sangat sering terjadi. Salah satu permasalahan yang menyita perhatian di dunia pendidikan zaman sekarang adalah kekerasan di sekolah (bullying). Tindak-an bullying adalah penekanan dari seorang atau sekelompok orang yang lebih senior, lebih kuat, lebih besar, lebih banyak terhadap seseorang atau bisa juga beberapa orang yang lebih lemah, lebih kecil maupun lebih junior. Kasus bullying kerap kali terjadi di sekolah.

Menurut penelitian yang dilakukan
Yayasan Semai Jiwa Amini (SEJIWA) tentang kekerasan bullying dikota besar di Indonesia, yaitu Yogya-karta, Surabaya dan Jakarta mencatat terjadinya tingkat kekerasan sebesar $67,9 \%$ ditingkat SMA dan $66,1 \%$ ditingkat SMP (Januarko, 2013). Berdasarkan hasil observasi selama keg-iatan Praktik Keterampilan Mengajar di SMK Negeri 41 Jakarta, tindakan bullying yang di-lakukan antara lain mengejek, memalak, bertengkar, bahkan kejadian itu tidak terjadi sekali atau dua kali saja, biasanya dilakukan oleh siswa kelas dua atau kelas tiga. Selama ini, guru BK hanya memberikan bimbingan kelompok bagi

\footnotetext{
${ }^{1}$ Mahasiswa Program Studi Bimbingan dan Konseling FIP UNJ, putrinuliandini@gmail.com

${ }^{2}$ Dosen Program Studi Bimbingan dan Konseling FIP UNJ, wirdahanim10@gmail.com

${ }^{3}$ Dosen Program Studi Bimbingan dan Konseling FIP UNJ, atiek.sismiati@yahoo.com
} 
pelaku bullying tanpa adanya suatu treatment (perlakuan) khusus yang diberi-kan, sehingga siswa belum sepenuhnya meny-adari bahwa selama ini perilaku mereka bermas-alah. Selain itu, berdasarkan hasil penelitian yang dilakukan oleh Nur Azizah pada tahun 2012, dapat disimpulkan bahwa bullying di SMK 41 masih terus terjadi.

Upaya yang dapat dilakukan oleh guru BK untuk menurunkan tingkat bullying siswa yaitu dengan melaksanakan kegiatan konseling kel-ompok dengan metode role play. Role play membantu siswa untuk melihat perilaku bullying yang selama ini ia lakukan terhadap teman ataupun adik kelas. Seorang anggota kelompok memainkan peran yang menjadi sumber masalah bagi seseorang anggota lainnya dan ia berbicara kepada anggota tersebut. Hal ini memungkinkan siswa untuk memperoleh umpan balik tentang tingkah lakunya saat ini dalam kelompok. Oleh sebab itu, penggunaan role play dalam konseling menjadi isu menarik bagi peneliti untuk menurunkan tingkat bullying siswa kelas XII di SMK Negeri 41 Jakarta.

\section{KAJIAN TEORI BULLYING}

Bullying didefinisikan sebagai suatu perilaku agresi baik secara fisik, verbal maupun psikologis, yang dilakukan seseorang atau sekelompok orang secara sengaja dan berkelanjutan untuk menyakiti atau mengganggu orang lain yang lebih lemah. Bullying adalah aktivitas sadar, disengaja, dan keji yang dimaksudkan untuk melukai, menanamkan kekuatan melalui ancaman agresi lebih lanjut, dan menciptakan teror (Coloroso, 2007). Bullying merupakan salah satu perilaku agresif dan negatif yang ditujukan untuk melukai dan menyakiti orang lain sampai korban merasakan bahwa perlakuan ttersebut membuatnya terintimdasi, tertekan, dan merasakan sakit hati.

Terdapat tiga jenis bentuk bullying yaitu bullying verbal, bullying fisik, dan bullying relasional. Bullying verbal dapat berupa julukan nama, celaan, fitnah, kritik kejam, penghinaan (baik yang bersifat pribadi maupun rasial), perampasan uang jajan atau barang-barang, telepon yang kasar, e-mail yang mengintimidasi, surat-surat kaleng yang berupa ancaman kekerasan, serta gosip yang keji dan keliru. Bullying fisik antara lain memukul, mencekik, menyikut, meninju, menendang, menggigit, mencakar, serta meludahi anak yang ditindas, dan merusak serta menghancurkan pakain serta barang-barang anak yang tertindas. Bullying relasional adalah pelehaman harga diri korban bullying secara sistematis melalui pengabaian, pengucilan, atau penghindaran. Perilaku ini dapat mencakup sikap-sikap tersembunyi seperti pandangan yang agresif, lirikan mata, helaan napas, bahu yang bergidik, cibiran, tawa mengejek, dan bahasa tubuh yang kasar.

\section{METODE ROLE PLAY}

Role play merupakan sebuah model pengajaran yang berasal dari dimensi pendidikan individu maupun sosial. Role Play dimainkan dalam beberapa rangkaian tindakan seperti mengurai-kan sebuah masalah, memeragakan, dan men-diskusikan masalah tersebut (Joyce, 2009). Metode role play merupakan metode yang dapat mendorong para siswa untuk memerankan, mendramatisasikan, dan melihat secara langsung situasi yang terkait dengan masalahmasalah, tanpa menggunakan naskah tertulis untuk kemudian mendiskusikan masalah-masalah tersebut. Metode ini membantu siswa untuk lebih memahami dan menganalisis per-masalahan sosial karena dalam prosesnya mereka terlibat dan melihat secara langsung bagaimana permasalahan tersebut diselesaikan.

Tujuan dari metode role play antara lain yaitu: (1) Mengeksplorasikan perasaan siswa, (2) Mentransfer dan mewujudkan pandangan mengenai tingkah laku, nilai, dan persepsi siswa, dan (3) Mengembangkan kemampuan pemecahan masalah dan tingkah laku (Joyce, 2009). Role play dapat menggambarkan perasaan siswa, baik perasaan yang hanya dipikirkan maupun 
perasaan yang dieks-presikan. Siswa yang melakukan role play menempatkan dirinya dalam posisi orang lain, dan mencoba berinteraksi dengan siswa lain yang juga bertugas memerankan. Melalui met-ode ini, siswa mempelajari watak orang lain, cara berhubungan dengan orang lain, dan cara memecahkan masalah yang ada.

Shaftels berpendapat bahwa role play terdiri dari sembilan langkah, yaitu: (1) Memanaskan suasana kelompok, (2) Memilih partisipan, (3) Mengatur setting tempat kejadian. (4) Meny-iapkan pengamat, (5) Memerankan, (6) Diskusi dan evaluasi, (7) Memerankan kembali, (8) Diskusi dan evaluasi, dan (9) Mengembangkan pengalaman (Joyce, 2009).

\section{KONSELING KELOMPOK}

Konseling kelompok adalah layanan perorangan yang di laksanakan dalam suasana kelompok. Di sana ada konselor (yang jumlahnya mungkin lebih dari dua orang) dan ada konseli yaitu para anggota kelompok (yang jumlahnya paling kurang dua orang). Di sana terjadi hubungan konseling dalam situasi hangat, terbuka, permisif dan penuh keakraban dimana ada pengungkapan dan pemahaman masalah klien, penelusuran sebab-sebab timbulnya masalah, upaya pemecahan masalah (jika perlu dengan menerapkan metode-metode khusus), kegiatan evaluasi dan tindak lanjut. Satu hal yang paling pokok adalah dinamika interaksi sosial yang dapat berkembang dengan intensif dalam suasana kelompok (Prayitno, 2004).

Tahapan-tahapan dalam konseling kelom-pok yaitu tahap awal, tahap pembentukan, tahap peralihan, tahap kegiatan, dan tahap peng-akhiran. Tahap awal, dilakukan upaya untuk menumbuhkan minat bagi terbentuknya kel-ompok. Tahap pembentukan, merupakan tahap pengenalan, tahap pelibatan diri atau tahap memasukkan diri ke dalam kehidupan suatu kelompok. Tahap peralihan, Tahapan untuk mengalihkan kegiatan awal kelompok hingga kegiatan berikutnya yang lebih terarah pada pencapaian tujuan kelompok. Tahap kegiatan, siswa secara aktif dan dinamis dalam membahas dan mengentaskan permasalahan. Tahap peng-akhiran, tahapan akhir kegiatan untuk melihat kembali apa yang sudah dilakukan dan dicapai oleh kelompok serta merencanakan kegiatan lebih lanjut (Prayitno, 2004).

\section{METODOLOGI PENELITIAN}

Penelitian ini bertujuan untuk mengetahui peng-aruh role play dalam konseling kelompok untuk menurunkan tingkat bullying pada siswa kelas XII di SMK Negeri 41 Jakarta. Penelitian ini dilakukan di SMK Negeri 41 Jakarta, sejak bulan April sampai Desember 2015.

Penelitian ini menggunakan pendekatan kuan-titatif dengan metode kuasi eksperimen pretest-posttest nonequivalent group design. Oleh sebab itu, penelitian ini akan melibatkan kelompok eksperimen sebagai kelompok yang akan men-dapatkan perlakuan dan kelompok kontrol yang tidak mendapatkan perlakuan. Kedua kelompok akan mendapatkan pretest dan posttest yang bertujuan untuk mengetahuipengaruh variabel independen $(\mathrm{X})$ yang tercermin dalam perbedaan variabel dependen khususnya $\mathrm{O}_{2}$ dan $\mathrm{O}_{4}$. Penelitian dilakukan sebanyak sepuluh kali per-temuan. Selama pelaksanaan eksperimen pen-eliti menggunakan role play dalam konseling kelompok untuk menurunkan tingkat bullying. Populasi dalam penelian ini adalah siswa kelas XII SMK Negeri 41 Jakarta Selatan, sebanyak tiga kelas yang terdiri dari 100 orang. Teknik sampling yang digunakan dalam penelitian ini adalah purposive sampling dengan sampel berjumlah 18 orang siswa, yaitu 9 orang siswa menjadi kelompok eksperimen dan 9 orang siswa untuk menjadi kelompok kontrol.

Penelitian ini menggunakan instrumen bullying yang dikembangkan dari teori Coloroso, terdiri dari tiga aspek yaitu verbal,fisik, dan relasional.Pengujian validitas akan dilakukan dengan meng-gunakan rumus Product Moment Pearson, didapati hasil 93 pernyataan valid dan 3 pernyataan drop. 
Pengujian realiabilitas menggunakan teknik Alpha Cronbach meng-gunakan interpretasi terhadap koefisien korelasi yang diperoleh atau nilai $r$ yang dilihat dari tabel interpretasi nilai r. Berdasarkan hasil uji reliabilitas yang telah dilakukan pada butir pernyataan yang valid, didapatkan angka reliabilitas sebesar 0,949 yang berarti tinggi, artinya instrumen bullying reliabel dan layak digunakan sebagai alat ukur dalam penelitian.

Pengaruh eksperimen terhadap sampel pen-elitian diketahui melalui pengolahan data dan analisis data menggunakan Mann Whitney U-Test dengan menggunakan ban-tuan aplikasi SPSS versi 20.0 .

\section{HASIL DAN PEMBAHASAN}

Berdasarkan hasil perhitungan dengan meng-gunakan Mann Whitney UTest deng-an SPSS 20.0, diperoleh data Asymp. Sig $=0,002<$ nilai signifikansi $\alpha$ 0,05 . Berdasarkan data tersebut, dapat disimpulkan bahwa $\mathrm{H}_{1}$ diterima dan $\mathrm{H}_{0}$ ditolak. Artinya, role play dalam konseling kelompok berpengaruh positif untuk menurun-kan tingkat bullying peserta didik kelas XII SMK Negeri 41 Jakarta yang menjadi subjek penelitian.

Data skor pretest-posttest tingkat bullying siswa pada kelompok eksperimen maupun kelompok kontrol, sebagai berikut:

Tabel 1

Data Skor Tingkat Bullying Kelompok Eksperimen

\begin{tabular}{|c|c|c|c|c|}
\hline \multirow{2}{*}{$\begin{array}{c}\text { Kelom- } \\
\text { pok }\end{array}$} & \multirow{2}{*}{ Nama } & \multicolumn{3}{|c|}{ Skor } \\
\hline & & $\begin{array}{c}\text { Pre- } \\
\text { test }\end{array}$ & Posttest & Penurunan \\
\hline \multirow{9}{*}{ 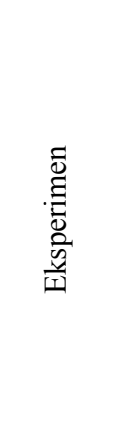 } & SDT & 231 & 217 & 14 \\
\hline & NLP & 211 & 165 & 46 \\
\hline & $\mathrm{AF}$ & 199 & 183 & 16 \\
\hline & IF & 195 & 179 & 16 \\
\hline & IN & 201 & 138 & 63 \\
\hline & US & 194 & 127 & 67 \\
\hline & $\mathrm{Y}$ & 200 & 171 & 29 \\
\hline & AR & 196 & 180 & 16 \\
\hline & $\mathrm{JN}$ & 190 & 156 & 34 \\
\hline
\end{tabular}

Grafik 1

Data Skor Tingkat Bullying Kelompok Eksperimen

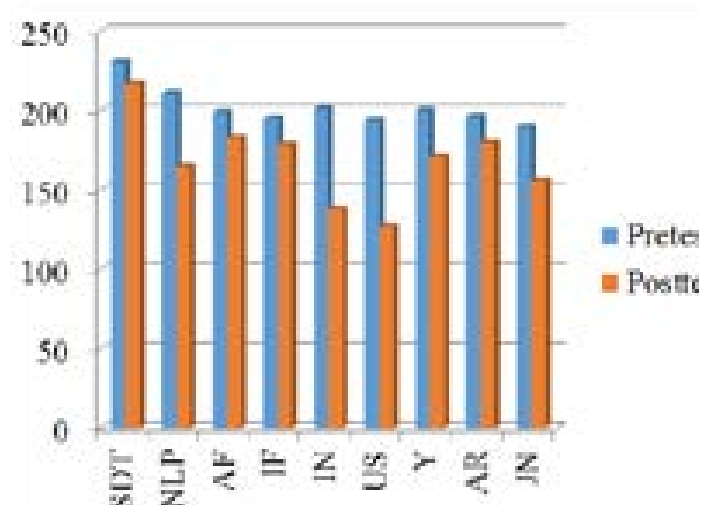

Tabel 2

Data Skor Tigkat Bullying Kelompok Kontrol

\begin{tabular}{|c|c|c|c|c|}
\hline \multirow{2}{*}{ Kelompok } & \multirow{2}{*}{ Nama } & \multicolumn{3}{|c|}{ Skor } \\
\hline & & Pretest & Posttest & Penurunan \\
\hline \multirow{9}{*}{$\begin{array}{l}\bar{O} \\
\stackrel{\Xi}{0} \\
0 \\
\underline{0}\end{array}$} & I & 196 & 194 & 2 \\
\hline & HR & 204 & 215 & -11 \\
\hline & ZPR & 197 & 188 & 9 \\
\hline & SD & 206 & 197 & 9 \\
\hline & AT & 191 & 184 & 7 \\
\hline & PRW & 190 & 189 & 1 \\
\hline & FGR & 211 & 176 & 35 \\
\hline & JIR & 198 & 196 & 2 \\
\hline & $\mathrm{R}$ & 202 & 197 & 5 \\
\hline
\end{tabular}

Grafik 2

Data Skor Tingkat Bullying Kelompok Kontrol 


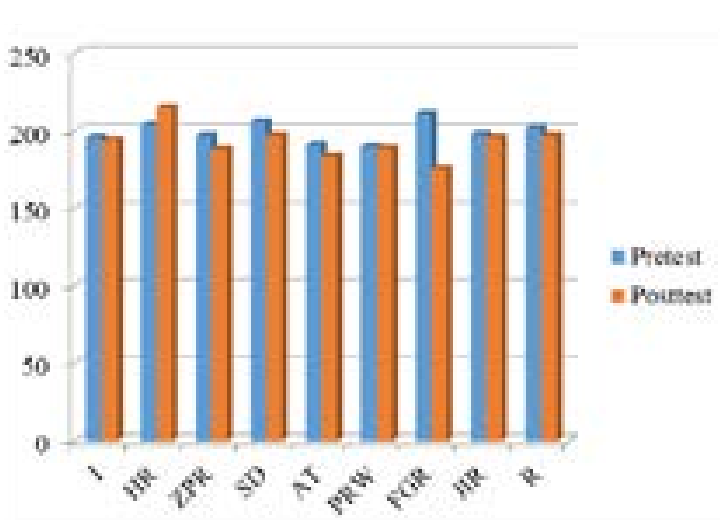

Berdasarkan data pretest dan posttest didap-atkan hasil bahwa terjadi penurunan skor pada kelompok eksperimen maupun kelompok kontrol. Penurunan pada kelompok eksperimen lebih besar jika dibandingkan dengan kelompok kontrol.

Selanjutnya, data per indikator bullying ber-dasarkan hasil pretest dan posttest pada kelompok eksperimen maupun kelompok kontrol, dapat diketahui sebagai berikut:

Tabel 3

Data Hasil Pretest dan Posttest Per Indikator Kelompok Eksperimen dan Kelompok Kontrol

\begin{tabular}{|c|c|c|c|c|}
\hline \multirow{2}{*}{ Kel. } & \multirow{2}{*}{ Indikator } & \multicolumn{3}{|c|}{ Skor } \\
\hline & & Pretest & Posttest & Penurunan \\
\hline \multirow{3}{*}{ 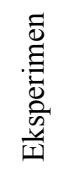 } & Verbal & 682 & 569 & 113 \\
\hline & Fisik & 743 & 630 & 113 \\
\hline & $\begin{array}{l}\text { Relas- } \\
\text { ional }\end{array}$ & 389 & 307 & 82 \\
\hline \multirow{3}{*}{$\begin{array}{l}\bar{O} \\
\vec{\Xi} \\
\underline{0}\end{array}$} & Verbal & 697 & 638 & 59 \\
\hline & Fisik & 719 & 712 & 7 \\
\hline & $\begin{array}{l}\text { Relas- } \\
\text { ional }\end{array}$ & 379 & 386 & -7 \\
\hline
\end{tabular}

Berdasarkan tabel diatas diketahui terjadi penurunan di setiap aspek pada kelompok eksperimen. Penurunan terbesar terdapat pada aspek verbal dan fisik yaitu sebesar 113. Sedangkan pada kelompok kontrol, terdapat satu aspek yang tidak mengalami penurunan yaitu pada aspek relasional. Pada aspek verbal dan fisik terdapat penurunan walaupun jumlahnya tidak sebesar penurunan yang terjadi pada kelompok eksperimen. Maka dari itu, diperlukannya konseling kelompok untuk men-urunkan tingkat perikalu bullying siswa dengan menggunakan metode role play.

Metode ini membantu siswa untuk lebih memahami dan menganalisis permasalahan sosial karena dalam prosesnya mereka terlibat dan melihat secara langsung bagaimana permasalahan tersebut diselesaikan.

Role play merupakan salah satu metode yang akan membantu siswa dalam megeksplorasikan perasaan serta mengembangkan kemampuan siswa dalam memecahkan masalah dan tingkah laku. Pada pelaksanaan konseling ini, sebagian besar siswa mulai mampu memberikan respons yang baik dalam setiap tahapan konseling. Mereka mampu mengikuti dengan baik walaupun pada awal pertemuan mereka terlihat malu-malu memerankan peran yang telah ditentukan. Sebagian besar dari mereka mengakui bahwa perilaku bullying mereka disebabkan oleh keadaan keluarga khususnya orang tua dan lingkungan pergaulan teman sebaya.

\section{KESIMPULAN DAN SARAN}

Berdasarkan hasil pengujian hipotesis dengan menggunakan teknik Mann Whitney U Test, diperoleh hasil nilai asymp. $\mathrm{Sig}=0,002$. Hipotesis penelitian diuji pada taraf signifikansi $\alpha=0.05$ atau dengan tingkat kesalahan 5\%, maka Nilai Asymp. Sig $=0,002<$ nilai signifikansi $\alpha=0.05$, maka dapat disimpulkan bahwa $\mathrm{H}_{0}$ ditolak dan $\mathrm{H}_{1}$ diterima. Ini mengartikan bahwa terjadi penurunan pada tingkat bullying siswa kelas XII di SMK Negeri 41 Jakarta setelah diterapkan metode role play dalam konseling kelompok. Metode role play dalam konseling kelompok dapat diterapkan untuk menurunkan tingkat bullying karena siswa memiliki kesempatan untuk melihat perilaku bullying yang selama ini mereka tampilkan 
dalam pergaulan di sekolah serta memberikan kesempatan untuk menganalisis perilakunya selama ini.

Bagi guru bimbingan dan konseling di sekolah dapat menjadikan layanan konseling kelompok dengan metode role play sebagai salah satu alternatif dalam menangani siswa yang ber-masalah dengan tingkat bullying yang tinggi.

Guru bimbingan dan konseling sebaiknya tetap memantau perkembangan responden penelitian dan melakukan tindak lanjut pembinaan responden setelah mengikuti layanan konseling kelompok dengan metode role play

\section{DAFTAR PUSTAKA}

Arikunto, S. (2006). Prosedur Penelitian: Suatu Pendekatan Praktik. Jakarta: Rineka Cipta.

Azizah, N. (2012). Bentuk-Bentuk Bullying pada Siswa Sekolah Menengah Kejuruan. Jakarta: BK UNJ.

Coloroso, B. (2007). Stop Bullying. Jakarta: Serambi Ilmu Semesta.

Joyce, B.M.W., \& Calhoun, E. (2009). Model of Teaching: Model-Model Pengajaran (8th ed.). (A. Fawaid \& A. Mirza, Trans.). Yogyakarta: Pustaka Pelajar.

Olweus, D. (1993). Bullying at School: What We Know and What We Can Do. New York: Blackwell Publishers.

Prayitno \& Amti, E. (2004). Dasar-Dasar Bimbingan dan Konseling. Jakarta: Rineka Cipta.

Yayasan Semai Jiwa Amini. (2008). Bullying: Mengatasi Kekerasan di Sekolah dan Lingkungan Sekitar Anak. Jakarta: Grasindo. 